smallest of existing rhinoceroses. Singularly enough, at the time this animal was on its way to England, a second specimen of the same species was received by the Zoological Society of Hamburg, and is now living in their gardens in that city. The Hamburg animal is likewise a female, and is said by those who have examined both individuals, to agree in nearly every particular with that belonging to the Zoological Society of London, but to be about one-third smaller.

It must be observed, that although the Sumatran rhinoceros has two horns, it is by no means nearly related to the African two-horned rhinoceros, but has the incisor teeth and other cranial characters of the Indian division of the group.

Of the African rhinoceroses, which constitute the second division of the genus as explained above, many nominal species have been made by naturalists who delight in conferring names upon fragments of horns, and imperfect skulls; but we have not as yet certain evidence of the existence of more than two species, commonly known as the Black rhinoceros and the White rhinoceros.

The Black rhinoceros (Rhinoceros bicornis of Linnæus) has its upper lip long and prehensile. This organ, in fact, forms almost a short proboscis, well fitted for grasping the small branches of trees, upon which it principally subsists. The two horns are not very different in size and length, although the front one is usually longest. The Black rhinoceros is found in Eastern Africa, as well as in the interior of the Cape Colony. In his well-known work on the Nile tributaries of Abyssinia, Sir Samuel Baker describes it as being not unfrequently met with in Upper Nubia. The young male example of this animal obtained by the Zoological Society in September 1868 , was captured in this district by the Hamram Arabs, of whose prowess Sir Samuel Baker tells us such wonderful stories. A living example of the African Black rhinoceros has been since added to the collection of the Zoological Society of Berlin; but these two specimens are, we believe, the only individuals of this species that have been brought to Europe, since the days when rhinoceroses were exhibited and slain in the Roman amphitheatres.

The White African rhinoceros is immediately distinguishable from its black brother, apart from the difference in the colour of its skin, by its short upper lip, whence Dr. Burchell, the first scientific traveller who met with it, proposed to call it Rhinoceros simus. It is a grazing animal, feeding chiefly upon grass, and inhabits more open districts than $R$. bicornis. But the most noticeable distinction of the White rhinoceros is the enormous length of the front horn, which in old individuals reaches to three and a half, or even four feet in length, and, after sloping forwards, curves gently backwards towards the summit. The hinder horn, on the contrary, always remains small, and slightly developed. The range of the White rhinoceros in Africa is not very perfectly known. From the inner parts of the Cape Colony it extends probably on to the Zambesi and its affluents. How much farther northwards it may go is uncertain ; but, according to Sir Sanuel Baker, it is not known in Upper Nubia, where the Black rhinoceros is the only species met with.

No specimen of the African White rhinoceros has yet been brought to Europe, and few additions could be made to the collection of the Zoological Society of London, which would be more acceptable than a young male of this rare and curious animal.

P. L. S.

\section{SCIENCE IN THE NAVY}

$\mathrm{T}^{\mathrm{T}} \mathrm{T}$ is with great satisfaction that we learn, from a speech made by $\mathrm{Mr}$. Goschen in the House of Commons last week, that the Government proposes a vote of $2,000 l$. to Mr. Archibald Smith, Q.C., for great services rendered by him to the Admiralty, not in his professional capacity, but as a man of science whose researches into matters connected with magnetism had been of great service to the Navy and the country. This grant was not proposed as a compensation for Mr. Smith's very laborious services, but as a small mark of the high appreciation the Government had of his eminent scientific services. There was another increase proposed also in aid of the expedition about to be organised under the auspices of the Royal Society to make researches into the depth, temperature, composition, circulation, and distribution of animal life in the Atlantic, Indian, and Pacific Oceans. The total cost to the country, supposing the inquiry to extend over two and a half years, would be about $25,000 l$, a sum which would not be grudgingly paid in order to secure a vast amount of important scientific knowledge.

The following announcement, with respect to the education of naval officers, will be welcomed with great satisfaction by the scientific public generally :-

"It was proposed that cadets should first go for two years to a Naval College, to master some of the rudiments of their profession, cruisers being attached, so that they might begin to go to sea. At the expiration of or within twelve months they world go out in a seagoing man-ofwar, with naval instructors, when they would have for three years a much better education than they now obtain, the same amount of sailoring experience being retained. It would then be desirable that they should have six months' teaching preliminary to their examination, when many young officers would ascertain which way their bent lay, and whether they should apply themselves to higher courses of study, for which arrangements could be made, but which would not be entered upon till they had passed the lieutenant's examination. . The question that the Government had before them in reference to this subject was how to unite in one establishment all the various branches of naval study which were at present taught in the Royal Naval College at Portsmouth, and in the Naval School of Architecture at South Kensington. At present the Royal Naval College conducted their examinations themselves-that is to say, they first taught and then examined, which was not at all a desirable state of things. It was now proposed to combine the scheme which he had described as regarded the education of the young officers with one for the education of the commissioned officer, and also to make better arrangements for the education of the Engineer and Marine officers. In order to carry out these objects it was proposed to found a Royal Naval College at Greenwich, where all branches of a general naval education would be taught, and to do so upon a scale which would be calculated greatly to raise the tone of our naval officers. In the first place there would be received in the College sub-lieutenants, who would be kept there for six months before their passing their general examination, and also naval officers. It was proposed that after the sublieutenants had passed their examinations and had been a short time at sea, those who chose to avail themselves of it should have an opportunity accorded to them of pursuing a higher course of study, of which half-pay officers might also avail themselves, and the establishment being so near London they should be able to offer a better course of study, under more able professors, than would be possible to give at Portsmouth. But, in addition to thus offering an education of this description to the young and to the commissioned officers who now went to Portsmouth, they trusted to be able to make arrangements with regard to the education of Engineer officers. At present these latter officers were all brought up in our own yards, which they entered at about fifteen or sixteen years of age, and in which they remained for four or six years as Engineering apprentices, and at the end of the fourth year three were selected to go to the School of Naval 
Architecture at South Kensington. In the same way, from a certain number of shipwrights' apprentices three or four were also selected every year to go up and study at the latter school. As regarded the Engineers, it was proposed that not merely three or four out of the thirty should be sent every year to South Kensington, but that all of them, after having been four years in the yards, should have the advantage of going through a course of one year's education at Greenwich, which should include all the higher branches of engineering education, such as metallurgy and chemistry. It was further proposed to take a similar course with reference to the shipwright's apprentices, but only as regarded a limited number, who would have an opportunity of studying naval architecture at Greenwich. The South Kensington School would be removed to Greenwich. . . With regard to the cadets, it was not proposed that they should go to Greenwich. No definite arrangements had as yet been proposed with reference to them, but that there was no great hurry in the matter, because in future they would not be taken under fifteen years of age, and it would be as well to wait until those who had entered at thirteen had attained the latter age before new arrangements were entered into with regard to them."

We heartily congratulate the Government on this commencement of a higher scientific instruction of officers of the Navy, and trust that the course thus commenced will be persisted in.

\section{NOTES}

The Royal Commission on Scientific Instruction and the Advancement of Science have, we are informed, concluded their inquiry into the scientific instruction afforded in training colleges and elementary schools, and in the science classes of the Science and Art Department.

THERE will be an election to a Natural Science Fellowship in Exeter College, Oxford, on Wednesday, June r9. The examination will be in Biology. The Fellow elected will be required to reside and take part in the instruction of the College. The election will take place under the conditions of the special ordinance of the College with regard to residence. The Fellow elected under the ordinance will be subject in all other respects to the Statutes of the College. The examination will probably begin on Tuesday, June $I$, and no person can be admitted as a candidate who has not passed all the examinations necessary for the degree of Bachelor of Arts in the University of Oxford, or been incorporated as a graduate in the University. Candidates are requested to make application by letter to the rector on or before June $I$.

THE examinations for Scholarships in Natural Science, which have recently been held at Clare and at Emmanuel College, Cambridge, have both terminated without an election being made. The reason of this is that at neither of the colleges did candidates present themselves, whose attainments, in the opinion of the examiners, entitled them to receive the distinction. The number of competitors was but small in each case, in one three only.

THE Vice-Chancellor of the University of Cambridge has promulgated the text of a memorial addressed to the University upon the subject of higher education, and adopted at a public meeting at Birmingham. It is similar to the memorials addressed upon the same subject from Rochdale, Leeds, Crewe, and the North of England Council for the Education of Women, and the prayer of the memorial is that a Syndicate be appointed to investigate the subject, and to inaugurate such means as would produce-firstiy, a standard of excellence in the departments of literature, science, and art, fixed by some universally recognised authority, and attainable by students of this class, which would secure for their studies the definiteness and thoroughness that are so much needed; secondly, an opportunity, offered to all who might be inclined to take advantage of it, of bringing their acquirements to the test of an examination; thirdly, the com mand of teaching power of a high order for the benefit of those who might wish to place themselves under instruction.

Prof. HuXley is, we learn from the Tinnes, the favourite candidate for the rectorship of St. Andrew's University.

THE following are the probable arrangements for the Friday evening meetings at the Royal Institution after Easter:-April I2, Mr. John Morley, "On Rousseau's Influence on European Thought;" April 19, Mr. Vernon Harcourt, F.R.S., "On the Sulphurous Impurity in Coal Gas and the means of removing it ;" April 26, Prof. Blackie, "On the Genius and Character of the Modern Greek Language." May 3, Wm. Spottiswoode, Treas. R.S.; May ro, N. Story-Maskelyne, F.R.S., "On Meteoric Stones ;" May I7, Prof. AkeI, F.R.S.; May 24, Prof. Clifford, "On Babbage's Calculating Machines;" May 3r, Mr. E. J. Poynter, A.R.A. June 7, Prof, Odling, F.R.S. And the following lecture arrangements are announced:-Dr. Wm. A. Guy, F.R.S., three lectures, "On Statistics, Social Science, and Political Economy," on Tuesdays, April 9, 16, and 23; Mr, Edward B. Tylor, F.R.S., six lectures, "On the Development of Belief and Custom amongst the Lower Races of Mankind," on Tuesdays, April 30 to June 4;" Prof, Tyndall, F.R.S., nine lectures, "On Heat and Light," on Thursdays, April i I to June 6 ; Mr. R. A. Proctor, five lectures, "On the Star Depths," on Saturdays, April 13 to May II ; Prof. Roscoe, F.R.S., four lectures, "On the Chemical Action of Light," on Saturdays, May 18 to June 8.

Prof. Thiselton Dyer is about to deliver a course of lectures on flowers and fruits to the Royal Horticultural Society, with the following titles:-Thursday, April Ir, "Flowers: their common plan of construction." April 25, Flowers: the variety in their forms, and how brought about." May 9, "Flowers: their colours and odours." May 23, "Fruits : their structure." June 6, "How seeds are sown in Nature." June 20, "Flowers and Fruits under cultivation." The lectures will commence at 3 P.M.

M. Schimper, the celebrated botanist and paleontologist, is the only one of the old professors in the French University of Strasburg who has consented to continue to hold his post under the German rule. M. Schimper is a Frenchman by birth and descent, and had been offered a superior position elsewhere by the French Government.

M. PrILlieux, the French botanist, having declined to continue an honorary Associate of the Leipsic Leopold Academy of Natural Science, some German professors call upon their country. men to return the "brevets" they have received from French scientific bodies. But it is satisfactory to see Dr. Virchow coming forward to warn his colleagues against imitating such a bad example.

AN ingenious patent is now being worked, by which leather for the sides of boots and shoes is rendered impervious to wet and damp by exhausting the air from the pores of the leather, and filling them up with a substance which unites with and adheres to the fibre, thereby strengthening without impairing the elasticity of the material. It is stated that the patent, known as "Fanshawe's Waterproof Leather," is not only likely to be largely employed for the purpose to which we have referred, but that when asphalte pavement becomes more general, it will be possible to shoe horses with a material as hard as the asphalte itself, and which will prevent them slipping.

A NOVEL and most interesting experiment in the field of elementary instruction has just been resolved upon in Saxony. Hitherto, as everywhere else, so in that small but highly. developed kingdom, the youth of the lower orders, upon being 